\title{
THE WESTERN BALKANS AND EU ENLARGEMENT - LESSONS LEARNED, WAYS FORWARD, PROSPECTS AHEAD
}

\author{
Zhidas DASKALOVSKI, PhD \\ Department of Political Science \\ University of Cyril and Methodius, Skopje \\ E-mail: daskalovski@hotmail.com
}

\begin{abstract}
This study examines the state of the EU enlargement process in the Western Balkans. A more strategic approach from the side of the EU is needed to engage with the region and its myriad challenges - from security to economic development to the rule of law. The Western Balkans are surrounded by EU member states, yet membership remains a remote prospect, and other players, such as Russia, are ready to step in. It is in the interests of the EU to foster a secure and prosperous region, but it has to persuade the region's elites and public alike that the accession process will bring about sustainable reforms, stability and prosperity. This necessitates an enhanced reform drive and better communication by the governments in the region. The EU should work with governments and civil society to improve the evaluation process of progress made, induce consensus on EU enlargement among competing political parties, and support enhanced regional cooperation mechanisms. The EU needs to overcome 'good neighbourly relations' conditionality by proactively intervening to overcome bilateral disputes, to open accession negotiations with all countries as soon as possible, and ensure that the accession process serves as a powerful motor to drive reforms and institutional transformation.
\end{abstract}




\section{INTRODUCTION}

European Union (EU) enlargement is under threat. There is little enthusiasm among European member states for further enlarging the Union. The slowing down of the EU integration process in the Western Balkans has been accompanied by a slowdown in investment in the region by EU member states. European states face different problems of their own making. Citizens across the continent feel less connected with the European supranational institutions and globalization processes. Economic progress has been stagnating and populist leaders have exploited anti-elitist feelings. In the Balkans leaders imitate and improve populist strategies. New regional powers, such as Turkey, Russia, and China threaten to use the impasse in the EU enlargement process. It is in the interests of the EU to foster a secure and prosperous region, but it has to persuade the region's elites and public alike that the accession process will bring about sustainable reforms, stability and prosperity. This necessitates an enhanced reform drive and better communication by the governments in the region. The EU should work with governments and civil society to improve the evaluation process of progress made, induce consensus on EU enlargement among competing political parties, and support enhanced regional cooperation mechanisms. The EU needs to overcome 'good neighbourly relations' conditionality by proactively intervening to overcome bilateral disputes, to open accession negotiations with all countries as soon as possible, and ensure that the accession process serves as a powerful motor to drive reforms and institutional transformation. This paper analyses the state of affairs and discusses the methods how best to invigorate the enlargement process.

\section{STATE OF PLAY IN THE ENLARGEMENT PROCESS}

The Stabilisation and Association Process (SAP) - as a tailor-made, country-bycountry, progressive approach and intermediate step on the path towards accession has, since May 1999, been the centrepiece of EU strategy towards the Western Balkans. On 19 and 20 June 2000, at the Santa Maria de Feira European Council, all Western Balkan countries were considered as potential candidates for EU membership. A few months later, on 24 November 2000, the prospect of possible accession to the EU was confirmed at the Zagreb Summit. At the Thessaloniki European Council in June 2003, 


\section{Seccurity}

all EU member states declared their 'unequivocal support to the European perspective of the Western Balkan countries' and that 'the future of the Balkans is within the European Union.'

Following Croatia's accession to the European Union (EU) on 1 July 2013, no candidate country is on track for membership before the end of the same decade. Beyond politics, EU investments in the region have also slowed down. Nationalism has remained a strong force in the region, and in some places it has been supplemented by the growth of Islamist radicalisation. Disillusioned Balkan youth have even headed to Syria to join the terrorist fighters of the Islamic State of Iraq and Syria (ISIS). Different regional powers, such as Turkey, Russia, China and the Gulf states, have begun to become more engaged in the region, sensing a business and geopolitical opportunity enhanced by the absence of a momentum towards EU enlargement.

Citizens in the region have grown wary while EU institutions and member states do not envisage further enlargement before 2020. Elites in candidate countries have become increasingly aware that the negotiations will take a long time. For example for the 2004 enlargement negotiations began on 31 March 1998 with the six best-prepared countries (Cyprus, Estonia, Hungary, Poland, the Czech Republic and Slovenia), and on 15 February 2000 with all the other candidate countries (Bulgaria, Latvia, Lithuania, Malta, Romania and Slovakia) All except Bulgaria and Romania became members in 2004, which means the negotiations lasted six years. Sofia and Bucarest joined the EU in 2007, negotiating for seven years. Croatia negotiated from 2005 to 2013. It is highly unlikely that any of the Western Balkan countries will be able to join the EU in such periods of time. Moreover, the Greek debt crisis dealt 'a serious blow to the enlargement narrative as one of sustained convergence, EU-driven modernisation, and increasing prosperity'. (O'Brennan, 2013:40) National leaders have tried to manipulate the situation to their own advantage, often disregarding the necessity of democratic consolidation and paying only lip-service to the EU accession process. Organised crime, corruption and immigration, or large-scale unrest, could pose greater threats to Europe-wide security and stability if the prospects of Western Balkan countries' accession fade into the distance. The Western Balkans and the EU need to recharge the EU enlargement process through a reinvigorated accession process and strategy. 


\section{MOVING FORWARD}

\section{Forging a consensus among elites to promote reforms}

Politicians in the region must comprehend that the consolidation of democracy depends on elite consensus and cooperation. A critical step for successful democratisation is the transformation of divided elites into consensually unified ones through an elite settlement of basic disputes among elites. An elite pact, settlement or political settlement is a 'relatively rare event in which warring national elite factions suddenly and deliberately reorganise their relations by negotiating compromises on their most basic disagreements'. (Burton and Higley, 1987:295) Alternatively put, formal and informal pacts between contending political actors can move relations from a stage of disruptive confrontation to one of respectful, consensusbased political competition between elite groups. This is needed in the Western Balkans as soon as possible.

The EU should apply pressure on political parties in the Western Balkans to defuse the 'winner takes all' mentality of political elites. Party dialogue and a culture of consensus-building over policy issues and institutions should be further promoted. To safeguard against the appropriation of the EU enlargement progress for the furtherance of party political interests, the EU should formally insist that candidates for key positions leading the respective country's accession process - Chief Negotiator, Minister and Deputy Minister of European Integration, Chair of the Parliamentary Committee for EU Enlargement and similar positions -are elected or appointed by a consensus among the political parties in the respective national parliaments. The more the ruling and opposition parties are formally engaged in the enlargement process, the less they will be inclined to take a confrontational stand against the necessary reforms. Consensual policymaking will decrease inter-party bickering and defuse the tensions that contribute to the 'winner takes all' mentality.

Although it might look as if the EU were trying to interfere in the internal affairs of the countries in the region, this move would signal to the elites and to citizens in the region that political settlement and consensus over EU enlargement is a crucial issue for the democratisation and socio-economic development of the Western Balkans. 


\section{Securiaty}

Problems related to corruption and party political influence on the independence of public institutions, the media, and electoral processes are prevalent throughout the Western Balkans, a point repeatedly made in the European Commission progress reports. To address these barriers to the EU integration of the region, the EU should use IPA II to further support reforms in the 'enlargement countries'. In particular, under the public administration reform and rule of law components of IPA II, the EU should increase the focus on strengthening the independence and the competencies of following types of public institutions:

- the state/national/supreme Audit Office,

- commissioner on freedom of information

- the Broadcasting Council/media regulatory body,

- the Ombudsman Office,

- anti-monopoly Commission

- special anti-corruption bodies, and

- the Electoral Commission.

Building consensus is a key issue here. The emergence of a system of election/appointment of officials heading these bodies through a consensual vote in national parliaments would increase the likelihood of the confirmation of highly qualified candidates by a strong majority. Among other things, the strengthening of the efficacy and the role of the above-mentioned institutions will in the short run influence the fairness of elections. Free and fair elections, where the results of the voting are not disputed by any party, should be an urgent priority.

\section{Engaging public opinion in the EU}

Enlargement without supportive constituencies in both places, among the candidate (and potential candidate) countries and EU member states, and enlargement regarded as a purely technical, elite-driven process that few people understand, will not survive the current erosion of trust. The situation today does not differ much from circumstances and public opinion in the EU five or ten years ago. The risk is that a failure to step up the enlargement process during the tenure of the Juncker Commission would result in weaker, more authoritarian Western Balkan states. However, elucidation of the potential drawbacks of non-EU action regarding 
enlargement will not suffice to convince the citizens of EU member states who oppose further expansion. More openness, transparency, clarity, and precise communication and data are needed. If significant progress is made in the reform process in the Western Balkan countries, and a successful EU communication strategy is implemented to communicate the evaluation of that progress, then it would become easier to convince the EU public, in particular in the more sceptical EU countries, to support the enlargement process. In other words, the dissemination to ordinary citizens of more easily accessible and comprehensible analysis in addition to the resources and materials produced by the European Parliament Information Offices (EPIOs), EC representations/delegations, Europe Direct network will serve in better presenting the results of the Western Balkan reforms to the European public and could become a crucial tool for the European Commission and the European Parliament as well as for the national governments of member states to promote and explain the benefits of further enlargement. In the next section we will discuss how to prepare such kind of an analysis.

\section{Transform Commission progress reports into accessible, results-oriented evaluations}

EU progress reports assess the respective countries' progress in complying with the Copenhagen accession criteria and the conditionality of the Stabilisation and Association Process. Progress is measured on the basis of decisions taken, legislation adopted and measures implemented in a yearly time frame, from October in the previous year to September in the current year. The reports are not sufficiently clear, to ordinary citizens at least, in the assessment of the progress made. In the reports on many occasions, the word 'progress' is used in tandem with specific adjectives (some further, further, limited, very limited, patchy, hampered, little, good, slow, very slowly) to indicate the level of improvement in specific chapters. It is far from clear, however, what is the difference between 'limited' and 'very limited', 'slow' and 'very slow', or how 'further' progress being made in certain policy areas has been evaluated.

Moreover, progress in some areas is easily defended by the ruling elites as general progress of the country and a good performance of the government as far as $\mathrm{EU}$ accession is concerned. With constrained media spectrum it is easy for government 


\section{Seccurity}

to ignore the 'limited' or lack of progress in certain other areas. On the other hand, opposition parties can easily focus and warn the public about the policy areas where the country has made little or no progress, blaming the government for not doing enough in the EU accession process. Civil society organizations that specialize in certain problematic area, say environmental protection, will have a completely different view on the progress made of the country, than say, a NGO working in the area of consumer rights, where the Report has found strong progress being made in the adoption and implementation of the relevant acquis. Very few think tanks and civil society organizations in the Western Balkans have capacities and analytical skills to assess the overall progress made. Civen the polarized political scene in the Western Balkans, where media and civil society organizations are considered closer to the ruling parties or the opposition, the Reports can serve as PR tools to praise or criticize the government work on EU accession in the past year. The reports should be more specific and concrete with easily comprehendible and quantifiable indicators. To make the progress reports mobilising factors for civil society actors, politicians and public administrators across the region, ESI suggests doing for each chapter - and for each country - what the EU did in the visa liberalisation process for the region: produce one document ('roadmap') that clearly sums up what the core requirements are under each policy area (or chapter) that every accession candidate should meet. (European Stability Initiative, 2014). The Reports would then also serve as a tool to compare progress made within a country throughout time, as well as in comparison with the other Western Balkan countries.

This transformation of the EU progress reports would help the discussions in the European Parliament and indirectly assist wider European audiences to better grasp the intricacies of the Western Balkans enlargement process. Clearer indicators would serve MEPs to produce more informative debate and resolutions. The Progress Report should also devote a new concluding section that would assess the communication strategies - both in terms of objectives set initially and the evaluation of the implementation of the strategy- of the EU and Western Balkan governments alike visà-vis the benefits and challenges of the EU accession process and the progress made in a given year. Furthermore, at the moment the progress reports relate to improvements made in a single year, not to a continuum of progress. The Progress Reports should be complemented with an annual analytical evaluation of how close to full compliance to 


\section{Security}

the acquis a country is. In the next section we will discuss who and how to prepare such kind of an analysis.

\section{Engaging public opinion in the region}

The European Commission and the European Parliament should urge the governments in the region to reshape their communication strategies regarding enlargement with specific and timely delivery of information on the reforms made. Western Balkan governments must be obliged to prepare and implement annual communication strategies on the benefits and challenges of the EU accession process and the progress made in a given year. Within the annual communication strategies, accountability concerning the adoption and implementation of the acquis would be increased by the dissemination to the public by Western Balkan ministries of quarterly reports. These communication strategies would be evaluated in the EU Progress Reports, both in terms of the clarity and appropriateness of the objectives set initially and the evaluation of the implementation of the strategies. If evaluated by the Commission, governments in the region will devote necessary resources to improved communication with its citizens on the EU accession process. The annual analytical think tank reports can support this evaluation through providing independent verified updates on the communication strategies of the Western Balkan countries.

More openness and information from a variety of sources, both governmental and non-governmental, would serve to mobilise public opinion in the Western Balkan countries to support further reforms. To enhance the overall process the European Parliament and the European Commission should also insist that governments in the Western Balkan countries provide open, accurate data to local policy research institutes so that they can produce informative reports based on up-to-date data. No good analysis can be produced on the effectiveness of a communication strategy on the progress in the EU accession process of a given Western Balkan country if reliable data is not provided to analysts, for example. In that respect, the EU delegations in the region should closely monitor the implementation of the Access to Information laws which typically aid researchers in situations where data is not easily available. IPA II projects on Western Balkan states achieving Open Government Partnerships should also aid the process. 


\section{Seccurity}

\section{Regional cooperation must improve}

Notwithstanding a number of open bilateral issues, regional cooperation among the Western Balkan states should be further enhanced with the proactive support of the EU and the Regional Cooperation Council (RCC) In particular, the EU should urge an enhanced role for the RCC in stimulating regional cooperation in a variety of fields, including soft ones such as education, science and culture. The RCC should continue to serve as a platform for the region's governments to evaluate the future of regional cooperation, specifically based on careful examination of the actual needs of states in the region. The EU should enhance the implementation of the RCC's SEE 2020 Strategy and monitor the convergence of its goals with those of the EU since SEE 2020 is closely following the vision of the EU strategy Europe 2020. Continuous EU support is necessary as key elements of the Strategy such as "transport, energy, competitiveness and integrated growth have secured support from the Prime Ministers of Western Balkans economies and several EU Member States through the Berlin Process." (RCC press release 2015)

Beyond the RCC, the role of other regional bodies, such as the Regional School of Public Administration (ReSPA), should be strengthened to aid the enlargement process. ReSPA should serve as a hub for supporting leading civil servants engaged in the EU negotiations. EU negotiations by individual countries should be open for monitoring by civil servants of other Western Balkan countries. Apart from discussions and negotiations over strategic issues civil servants from the region should be able to monitor the negotiations and acquire practical knowledge of the process to be replicated in their own countries. This kind of regional cooperation should be enhanced by the EU and ReSPA. Regional initiatives, such as the SEECP, should also be supported by the EU, especially if the region is to focus on cooperation in solving a number of common problems such as corruption and political party influence on the independence of public institutions, the media, and electoral processes.

\section{Revisit 'good neighbourly relations' conditionality}

When EU conditionality touches upon identity politics, the transformative power of the $\mathrm{EU}$ is weak and ineffective. A problem arises when 'a state's national 


\section{Secururity}

identity contradicts the conditions linked to the benefit of an external incentive, the state will not or only inconsistently comply with these conditions independently of the expected costs of adaptation', and that 'national identity plays a crucial role as filter by sorting out whether governmental action is to be based on cost-benefit calculations ("logic of expected consequences") or in accordance with socially constructed and accepted identities, rules, and practices.' (Freyburg and Richter, 2008:14) In other words, if the conditionality criteria pertain to an issue area perceived as problematic for national identity, a different line of reasoning will be triggered than in cases where the criteria are considered unproblematic. National identity 'determines the logic of social action that governments will follow when responding to the Union's conditionality criteria'. (Freyburg and Richter, 2010:266)

The EU condition for the Macedonia to reach a 'negotiated and mutually acceptable solution on the name issue' is effectively hidden under the 'good neighbourly relations' criteria. (European Commission, 2009:6) Failing to achieve good neighbourly relations is in fact, pushing the Macedonia to negotiate on its name and identity. This amounts to posing additional unprecedented criteria for membership of the EU and NATO, a policy that delegitimises the principle of 'conditionality', one of the main instruments of the EU in the enlargement process. The blocking of the Macedonia's EU accession drive removes the major incentive for the country's political elites to work towards membership. Moreover, there is a high risk that Macedonian public opinion will turn against accession. More importantly, the possibilities for further soft mediation of Macedonian-Albanian political disputes will diminish at a time when there is a danger that nationalism and ethnocentrism will rise again.

Serbia has been trying to keep its policy on Kosovo separate from its aspiration to join the EU. However, since the EU has made clear that Serbia's progress towards accession depends on improving its relations with Kosovo, it might lead the country to take another look at the integration process. Despite the change of government in Serbia, the policy and discourse on Kosovo remains the same. It seems that no government in Belgrade in the near future will recognise Kosovo's independence. As it is very unlikely that the EU will have Serbia as a member if it does not establish good neighbourly relations with an independent Kosovo, the danger is that Belgrade will abandon EU enlargement, further complicating Balkan affairs. Serbia should be allowed to tackle this issue at the very end of the negotiations process. It would not be prudent to push Serbia on recognition of Kosovo when five Member states do not recognize 
Prishtina. While negotiations last and normalization of relations between Belgrade and Prishtina progresses the status of the Serbian minority in Kosovo must be upheld with a special attention to the Serbian municipalities in the North. If in due time the situation of Serbs in Kosovo is well accepted by the public in Serbia there might be a window of opportunity that Belgrade recognizes the independence of Prishtina at the time when the country would be acceding to the EU. EU conditionality runs the risk that it will not be taken seriously by other governments in the region that have or might have problems in bilateral relations with their neighbours or in regional cooperation. If the upper hand in bilateral disputes within the regional cooperation conditionality lies in the hands of one or more EU member states, laggards in the process of EU enlargement such as Kosovo might worry that they will suffer insurmountable obstacles in the accession process once Serbia joins the EU. If and when Serbia accedes to the EU special controlling mechanism should be put in place in order to secure that Belgrade would not be able to block progress of Kosovo's accession. Although such mechanism would be an unorthodox measure, given the experience with the Cooperation and Verification Mechanism for Bulgaria and Romania, it would not be a completely unorthodox measure. The credibility of the enlargement process 'remains in doubt so long as individual member states continue to make the accession process hostage to bilateral complaints, thereby undermining the element of fairness in the conditionality principle'. (Fouéré, 2014:8)

The view of the European Commission that 'bilateral issues should not hold up the accession process which should be based on established conditionality' (Enlargement Strategy 2014: 17)' should be given more political weight. In principle a way must be found to prevent the postponement of EU enlargement to certain Western Balkan countries as a result of veto-wielding powers by member states around the principle of 'good neighbourly relations' conditionality. A blockade of the enlargement process for Serbia and the Macedonia could have serious implications for regional stability and innovative solutions such those proposed above should be found. The EU should consider devising mechanisms/informal bodies to help solve specific bilateral disputes between member states and candidate countries. At some instances the EU can rely on most active/interested Member States. The German/British initiative in Bosnia is an example of individual member states pushing for resolution of problematic issues when the EU as a whole does not. While not all bilateral disputes merit such an effort, it is necessary in some, particularly difficult cases that revolve around the 


\section{Seccurity}

questions of statehood or national identity. The experience of the resolution of the Slovenia-Croatia sea border dispute should be considered, and an enhanced role and powers for the European Commission and/or the European Parliament in this process might be an option.

\section{CONCLUSIONS AND RECOMMENDATIONS}

In recent decades, the EU has invested so much in the Western Balkan region that the region is now strongly integrated economically with the EU, which accounts for more than two-thirds of the region's total trade. Therefore, an exit strategy should not be under consideration. On the contrary, closer integration should be moving further ahead. A deceleration of the accession process would seriously undermine the credibility of the EU and its self-proclaimed 'soft power', leaving the door open for the stronger influence of rising regional powers such as Russia. The increasingly indifferent feelings towards the EU from the side of elites in the Western Balkans have begun to usher in a return to authoritarian tendencies. Nationalism could easily rise in the region. New conflicts could develop, especially in the Macedonia, Kosovo or Bosnia and Herzegovina. The decline of influence by the EU could be exploited by regional powers such as Russia or Turkey. Given the visa-free travel to the EU Schengen countries for the Western Balkan countries (except Kosovo), there is a danger that radicalised Islamic youth from the Balkans would move in and become active in Europe. Organised crime, corruption and immigration could also emerge as potential threats to Europe-wide security and stability if the Western Balkan countries' accession is postponed indefinitely. The Western Balkans and the EU need to recharge the EU enlargement process through a reinvigorated accession process and strategy.

To do so an important target audience should be the EU public. The Western Balkans are not a priority for ordinary EU citizens. The countries do not have a good reputation - following years of negative media reports from the region and stereotyping within the EU resulting from reports of criminality caused by migrants from the Western Balkans. As the EU is undergoing an internal crisis, and its member states are less likely to be supportive of enlargement, the European Commission should take greater initiative by using clear language explaining to citizens of the EU and the Western Balkans the benefits of the accession process and the reforms required to join 
the EU. The public in the Western Balkans should also become more aware of the intricacies of the accession process and know better where their respective countries stand, and why some have not progressed further. Hence, better produced EU progress reports and reports by independent think-tanks in the Western Balkans are needed together with more precise and timely communication from the governments in the region.

Transparency and accountability are needed in the reforms, hence more accent should be placed on improving institutions and agencies that monitor and evaluate public policymaking. Elites in the Western Balkans must be induced to drop the prevalent confrontational mentality and move from disunity to unity in working together to further the enlargement process and democratic rule in general. Regional cooperation should be enhanced, and the EU should assist this through the various forms of multilateral institutions currently in place. There is no point in working on EU accession if the region does not improve and does not coordinate better its own activities and projects aiming to help the life of ordinary citizens. Brussels should accept that some of the regional problems, especially those involving bilateral issues and concerning 'good neighbourly' relations, will remain unresolved without the EU's direct involvement. Overall, devoid of EU accession prospects, the Western Balkan countries face the risk of a social-economic implosion and authoritarian consolidation. The Western Balkan countries need more assistance and attention from the EU than the Central European candidates that acceded to the EU in and since 2004. A set of concrete measures were suggested in the paper in order to revitalise the enlargement process.

\section{References}

1. Burton, M., and Higley, J., 'Elite Settlements', American Sociological Review, Vol. 52, No. 3, June 1987.

2. European Commission, Enlargement Strategy and Main Challenges 2014-2015, the Communication from the Commission to the European Parliament, the Council, the European Economic and Social Committee and the Committee of the Regions, Brussels, 2014. 
3. European Commission, Five Years of An Enlarged EU - Economic Achievements and Challenges, Communication from the Commission to the Council, Parliament, European Economic and Social Committee, Committee of the Regions and the European Central Bank, Brussels, 20 February 2009.

4. European Stability Initiative (ESI), Vladimir and Estragon in Skopje: A Fictional Conversation on Trust and Standards and a Plea on How to Break a Vicious Circle, European Stability Initiative (ESI), 2014.

5. Freyburg, T., and Richter, S., 'National Identity Matters: the Limited Impact of EU Political Conditionality in the Western Balkans', Journal of European Public Policy, No. 17(2), 2010.

6. Freyburg, T., and Richter, S., 'National Identity Matters: the Limited Impact of EU Political Conditionality in the Western Balkans', National Centre of Competence in Research (NCCR), Zürich: Challenges to Democracy in the 21st Century, Working Paper No. 19, 2008.

7. Fouéré, E., 'The EU's Enlargement Agenda - Credibility at Stake?, CEPS Policy Brief, No. 324, Centre for European Policy Studies (CEPS), Brussels, 31 October 2014.

8. O'Brennan, J., Enlargement Fatigue and its Impact on the Enlargement Process in the Western Balkans in The Crisis of EU Enlargement, London School of Economics (LSE) Special Report, London, 2013.

9. RCC Press release, 'Governing Board of RCC's SEE2020 Strategy Meets in Tirana,' 21.05.2015 